\title{
Studies on Practices of Artificial Insemination in Manipur
}

\author{
Ningthoukhongjam Linda ${ }^{1^{*}}$, Fazal Ali Ahmed ${ }^{1}$, K. Lalrintluanga ${ }^{1}$, \\ Dibyajyoti Talukdar $^{1}$ and Jyoti Pawan Chutia ${ }^{2}$ \\ ${ }^{1}$ College of Veterinary Sciences \& A.H., Central Agricultural University, \\ Selesih, Mizoram, India \\ ${ }^{2}$ Animal Husbandry and Veterinary Department, Govt. of Assam, India \\ *Corresponding author
}

\section{A B S T R A C T}

\begin{tabular}{l} 
K e y w o r d s \\
Artificial \\
$\begin{array}{l}\text { Insemination, } \\
\text { Frozen semen, } \\
\text { Conception rate }\end{array}$ \\
\hline Article Info \\
$\begin{array}{l}\text { Accepted: } \\
\text { 24 October } 2020 \\
\text { Available Online: } \\
10 \text { November } 2020\end{array}$ \\
\hline
\end{tabular}

The present study was undertaken in the four districts viz., Imphal West, Imphal East, Thoubal and Bishnupur district of Manipur, India with the objective of present practices of Artificial Insemination (AI) services among the dairy farmers. Although AI was introduced only in the early 1980's it has become widely adopted in the region. The overall choice of frozen semen was Holstein Friesian $(56.67 \%)$ followed by Jersey (36.67\%) and Red Sindhi (6.66\%). The timing of insemination was found highest during the mid-heat $(95.00 \%)$ where the semen was deposited at the cervix $(100 \%)$ and thawing of semen using lukewarm water was $46.67 \%$. Higher success rate and adoption of AI services was found higher in Below Poverty Line (BPL) farmers $(60.00 \%)$ than Above Poverty Line (APL) farmers $(40.00 \%)$ with the highest adoption rate of AI services amongst BPL farmers in Imphal West District $(80.00 \%)$. The overall conception rate was found to be highest in Imphal West district $(49.18 \%)$ and lowest in Thoubal district $(30.78 \%)$ with the overall conception rate of $37.96 \%$ in all the four districts during the study period. Highest milk production was recorded in Imphal West district $(26.67 \%)$ and lowest in Thoubal and Bishnupur district (13.33\%). In conclusion, AI adoption rate was quite average with the lower conception rate and the benefits from the services were still not satisfactory.

\section{Introduction}

The state of Manipur is located in the northeastern part of India and Imphal West/ East districts lies between $24.30^{\circ} \mathrm{N}$ and $25.00^{\circ} \mathrm{N}$ latitudes and between $93.45^{\circ} \mathrm{E}$ and $94.15^{\circ} \mathrm{E}$ longitudes, surrounded by Kangpokpi district In the north, Ukhrul district in the east, Thoubal district in the south-east, Bishnupur district in the south and Noney district in the west. According to the $19^{\text {th }}$ livestock census 2012, the state had 2.63 lakh cattle head out of which, 2.19 lakh were indigenous cattle and the rest were 0.44 lakh cross bred, but these indigenous cattle were not registered and still known as desi cattle (Pundir and Dangi, 2015). Cattle serves to be one of the most sources of income/livelihood to many people of the state dairy industry being a key part of the livestock sector and production of 
milk per day from the crossbred and indigenous cattle in the state were recorded $7.26 \mathrm{~kg}$ and $1.76 \mathrm{~kg}$ respectively (Pundir and Dangi, 2015) with per capita milk availability of $88 \mathrm{ml}$. In order to increase the milk production, farmers opt to breed their cows with imported semen of Holstein Friesian (HF), Jersey and Red Sindhi breeds. Some of the milk corporate which was producing pasteurized toned milk in the state of Manipur was supplying milk the state at a selling price of Rs.25.00 per packet of $500 \mathrm{ml}$.

With a view to increase dairy production and amelioration of local cattle breeds in the state, subsidized Artificial Insemination (AI) services, were presently available in the state of Manipur by the Department of Veterinary and Animal Husbandry Services, Government of Manipur.

Artificial Insemination practice has been improved considerably since commissioning of the Liquid Nitrogen $\left(\mathrm{LN}_{2}\right)$ production plant during 1991. As there is no semen collection centre from bulls in Manipur, therefore semen was brought from Sabarmati Ashram Goushala (NDDB), Ahmedabad. A liquid nitrogen production plant (Cryogenerator made in Holland by STIRLING) has been installed at the Integrated Cattle Development Project (ICDP), Porompat, Imphal which supplies required liquid nitrogen to all substations in the state. Total cost (per straw) including the price of semen, liquid nitrogen, transportation charges, technician or labour wages, etc. is Rs. 1,400.00 (sex assorted) and Rs.24.00 (frozen semen) which was made available to the beneficiaries at a nominal levy of Rs.10.00 (rupees ten) only to be collected by the inseminator as and when AI is carried out.

Once, the oestrus signs were displayed by the cows they were bred within four to twelve hours (Hammonds, 2016)but still many of the farmers abide to the a.m.- p.m. rule. The calls for Artificial Insemination were received either through mobile phones or at the veterinary district hospitals (including subcenters) and animals were inseminated with the frozen semen. Performing the insemination, semen is thawed at $37^{\circ} \mathrm{C}$ temperatures for approximately forty seconds. A confirmatory for pregnancy has been checked to verify whether the insemination was successful as the insemination process is not always effective (Hammonds, 2016).

Artificial Insemination has many benefits, both economically and the safety of herdsmen. Firstly, a farmer is able to choose the bull from which to use the semen which allows the selection of bulls with high genetic capacity thereby getting higher level of milk production from the offspring and more rapid breed amelioration (Bayemi, 2012; Shehu et al., 2010). Secondly, artificial insemination increases long-term herd health, as it reduces the frequency of sexually transmitted diseases (Bayemi, 2012; Shehu et al., 2010).

Further, an additional advantage is that Artificial Insemination practice allows greater/better efficiency with lower reproduction costs, as one bull can produce over 1,00,000 straws of semen annually and breed only with a few dozen females each year, which eventually decreases the cost of breeding a single cow (Bayemi, 2012; Funk, 2006). In the present study an attempt was made to study the practices of AI under the field conditions in four districts of Manipur.

\section{Materials and Methods}

The study was undertaken systematically for a period of five months i.e. from August, 2019 to December, 2019across the four districts (plain areas) namely Imphal West district, Imphal East district, Thoubal district, and Bishnupur district of Manipur. 
The cows are maintained under intensive system of management (stall feeding plan). They were fed with adequate grain, hay, grasses, mineral mixture supplemented with concentrate ration along with ad-libitum water for drinking purposes.

The data were collected from both regional and sub-stations also from the cow owners (no of questionnaires; $15 \times 4=60$ ) was collected through the corrected semi-structured interview schedule (Hammonds, 2016) from the district veterinary officers, in-charge of ICDP along with the beneficiary farmers to determine practices and usage, economic status of farmers, average conception rate and benefits to the farmers. The data were subjected to statistical analysis by using descriptive analysis.

\section{Results and Discussion}

\section{Practices and usage}

It was observed that $66.66 \%$ of farmers preferred Holstein Friesian semen in Imphal West district and 53.34\% in Thoubal district. Highest adoption rate was $46.67 \%$ in Imphal East district followed by $(33.34 \%)$ with the overall distribution of preferred choice of Holstein Friesian (56.67\%), Jersey (36.67\%) and Red Sindhi (6.66\%). (Table: 1). Many farmers used Holstein semen as generally they are very high milk producers, but some farmers opted for Jersey semen, which might be due to small size requiring less feeding and water which holds similar with the findings of (Hammonds, 2016).

The timing of insemination after oestrus detection was reported to be highest during mid heat $(100 \%)$ in Imphal West and Bishnupur district followed by early heat $(13.34 \%)$ with Thoubal district. The overall timing of insemination was found highest during mid-heat $(95 \%)$, followed by early heat and late heat insemination $3.34 \%$ and $1.66 \%$ respectively (Table 2 ).

The study reported that in all the four districts the practiced site of semen deposition is at deep cervix (100\%) where the semen deposition practicing at uterine horns and uterine body were found nil in all the four district.

The thawing techniques practiced in Imphal West district found highest using lukewarm water $(60.00 \%)$ followed by using water maintaining at $37^{\circ} \mathrm{C}$, measured by Breeder's thermometer $(35.00 \%)$ and pocket thawing at $5.00 \%$ respectively(Table: 3 ). Thawing of semen in warm water $\left(35-38^{\circ} \mathrm{C}\right)$ for 40 seconds increases fertility and conception rate rather than practicing air and pocket thawing (Dejarnette and Marshall, 2005; Kaproth et al., 2005) and the results were similar with the reports of Patel et al., (2017).

Table.1 Frequency distribution of preferred choice of bull semen for AI in four districts of Manipur $(\mathrm{n}=15)$

\begin{tabular}{|l|c|c|c|}
\hline District & HF (\%) & Jersey (\%) & Red Sindhi (\%) \\
\hline Imphal West & 66.66 & 33.33 & 0 \\
\hline Imphal East & 46.67 & 46.67 & 6.66 \\
\hline Thoubal & 53.34 & 33.34 & 13.32 \\
\hline Bishnupur & 60 & 33.34 & 6.66 \\
\hline Overall & 56.67 & 36.67 & 6.66 \\
\hline
\end{tabular}


Table.2 Frequency distribution for time of inseminations in four districts $(n=15)$

\begin{tabular}{|l|c|c|c|}
\hline District & Early heat (\%) & Mid-heat (\%) & Late heat (\%) \\
\hline Imphal West & 0 & 100.00 & 0 \\
\hline Imphal East & 0 & 93.34 & 6.66 \\
\hline Thoubal & 13.34 & 86.66 & 0 \\
\hline Bishnupur & 0 & 100.00 & 0 \\
\hline Overall & 3.34 & 95.00 & 1.66 \\
\hline
\end{tabular}

Table.3 Frequency distribution for thawing techniques practiced in four districts $(n=15)$

\begin{tabular}{|l|c|c|c|}
\hline District & $\begin{array}{c}\text { Lukewarm water } \\
(\mathbf{\%})\end{array}$ & $\begin{array}{c}\text { Pocket/air/hand } \\
\text { thawing } \mathbf{( \% )}\end{array}$ & $\begin{array}{c}\text { Using breeder's } \\
\text { thermometer (\%) }\end{array}$ \\
\hline Imphal West & 60.00 & 5.00 & 35.00 \\
\hline Imphal East & 46.67 & 40.00 & 13.33 \\
\hline Thoubal & 40.00 & 33.33 & 26.67 \\
\hline Bishnupur & 40.00 & 33.33 & 26.67 \\
\hline Overall & 46.67 & 31.67 & 21.66 \\
\hline
\end{tabular}

Table.4 Conception rate in the four districts from August to December $2019(n=15)$

\begin{tabular}{|c|c|c|c|}
\hline District & Month & $\begin{array}{c}\text { Conception rate } \\
(\%)\end{array}$ & Overall conception rate $(\%)$ \\
\hline \multirow{5}{*}{ Imphal West } & August & 46.23 & \multirow{5}{*}{49.18} \\
\hline & September & 43.30 & \\
\hline & October & 56.80 & \\
\hline & November & 51.02 & \\
\hline & December & 46.52 & \\
\hline \multirow{5}{*}{ Imphal East } & August & 47.05 & \multirow{5}{*}{37.47} \\
\hline & September & 31.60 & \\
\hline & October & 30.60 & \\
\hline & November & 39.53 & \\
\hline & December & 38.60 & \\
\hline \multirow{5}{*}{ Thoubal } & August & 34.88 & \multirow{5}{*}{30.78} \\
\hline & September & 30.40 & \\
\hline & October & 28.60 & \\
\hline & November & 30.16 & \\
\hline & December & 29.90 & \\
\hline \multirow{5}{*}{ Bishnupur } & August & 52.16 & \multirow{5}{*}{34.43} \\
\hline & September & 40.50 & \\
\hline & October & 30 & \\
\hline & November & 31.50 & \\
\hline & December & 18.00 & \\
\hline $\begin{array}{l}\text { Average } \\
\text { conception rate }\end{array}$ & \multicolumn{3}{|c|}{$37.96 \%$} \\
\hline
\end{tabular}


Table.5 Distribution responses of the AI farmers regarding their perceptions of advantages of AI use on their farms in four districts

\begin{tabular}{|l|c|c|c|c|c|}
\hline \multirow{2}{*}{ District } & \multicolumn{5}{|c|}{ Parameters (\%) } \\
\cline { 2 - 6 } & $\begin{array}{c}\text { Milk } \\
\text { production }\end{array}$ & $\begin{array}{c}\text { No need of a } \\
\text { bull }\end{array}$ & More revenue & $\begin{array}{c}\text { Better } \\
\text { offsprings }\end{array}$ & $\begin{array}{c}\text { Lack of sexually } \\
\text { transmitted diseases }\end{array}$ \\
\hline Imphal West & 26.67 & 13.33 & 26.67 & 6.66 & 26.67 \\
\hline Imphal East & 20.00 & 26.67 & 20.00 & 13.33 & 20.00 \\
\hline Thoubal & 13.33 & 26.67 & 20.00 & 20.00 & 20.00 \\
\hline Bishnupur & 13.33 & 20.00 & 26.67 & 13.33 & 26.67 \\
\hline Overall & 18.33 & 21.66 & 93.34 & 53.32 & 23.33 \\
\hline
\end{tabular}

\section{Economic status of farmers}

The economic status of farmers affected significantly on the success rate and adoption of AI. The animals owned by below poverty line (BPL) group of farmers recorded higher success rate and adoption of AI (60.00\%) compared to above poverty line (APL) category of farmers $(40.00 \%)$.It was found that in Imphal West district adoption of AI was highest among the BPL group of farmers $(80.00 \%)$ with lowest adoption by APL farmers $(20.00 \%)$.

Similar observations were also reported by Bhagat and Gokhale (2016). The popularity of adoption and usage amongst the BPL section of society may be the factor being major livelihood sources resulting in caring animals in-spite of less resources when compared with APL group of farmers.

\section{Average conception rate}

The conception rate and overall conception rate in the four districts were depicted in Table: 4 . The overall conception rate recorded was $37.96 \%$ which was remarkably lesser than the tropical conditions animals in Bihar (Bhagat and Phadke, 2019) crossbred animals in Maharashtra (Bhagat et al., 2008; Bhagat et al., 2009), and warm weather animals in Wardha district of Maharashtra (Shindey et al., 2014), and almost equivalent to that of animals from Bangladesh (Razi et al., 2010). Qureshi et al., (2008) also reported higher conception rate in Holstein crosses in hilly regions of Jammu.

\section{Benefits to the farmers}

Through AI services the overall achievement in milk production during the study period in the four districts were found to be $18.33 \%$ with absence of bull in the herd (43.33\%), higher revenue $(93.34 \%)$, better offsprings $(53.32 \%)$ and reduction of sexually transmitted diseases (23.33\%) respectively (Table: 5).

Although the AI has benefitted the farmers right from an increase in milk production, heard health, overall farm value, better offsprings and lack of sexually transmitted diseases however the results were less when compared with the findings of Hammonds, (2016) in tropical regions.

In conclusion the data on 5,174 artificial inseminations (AI) performed during 5 months (August, 2019 to December, 2019) spread across four districts of Manipur (Imphal West, Imphal East, Thoubal and Bishnupur districts) were analyzed and revealed that AIbreeding services and it use were not generally satisfactory and the conception rate is quite low when compared with the available reference. It is seen that the 
desired effect in terms of improvement and overall benefits to the farmers of AI services has not been achieved. Therefore, the government have to design and implement strategies for managemental practices in field conditions during insemination, herd management, care of pregnant cows, milk storage and prevention etc., then an increase in productivity through AI services will be flourished in the region. Furthermore, awareness amongst the farmers must be conducted and forwarded through researchers and extension experts to mend the loophole.

\section{Acknowledgement}

The authors are thankful to the Project Officer In-charge (ICDP, Porompat), District Veterinary Officers and staffs of Department of Veterinary and Animal Husbandry services, Manipur for providing necessary information and facilities in conducting the research work. The authors are also thankful to all the respondents for sharing their views in this study.

\section{Conflict of interest statement}

Authors declare no conflict of interest.

\section{References}

Bayemi, P.H. (2012). Science and Technology for Livestock Value Chain Development: A focus on Artificial Insemination. Technical centre for agricultural and rural coopération ACPEU. Institute of Agricultural Research for Development. Retrieved from https:// www.scribd.com.

Bhagat, R. L., Gokhale, S. B., Pande, A. B and Phadke, N. L. (2008). Socioeconomic factors influencing conception rate in cattle under field conditions. Indian Veterinary Journal.85:416-18.
Bhagat, R.L., Gokhale, S.B., Gokhale, R.B., Pande, A. B and Karbade, V. G. (2009). Reproduction attributes affecting conception rate in crossbred cattle. International Journal of Tropical Agriculture. 27(1-2): 169-72.

Bhagat, R. L and Gokhale, S. B. (2016). Studies on factors influencing conception rate in rural cattle. Indian Journal of Animal Sciences. (5):550-52.

Bhagat, R.L., and Phadke, N.L. (2019) factors affecting conception rate in $\mathrm{AI}$ bred cattle under field conditions of Bihar. Indian Journal of Animal Sciences. 89(1): 110-112.

Dejarnette, J. M and Marshall, C.E (2005). Straw-thawing method interacts with sire and extender to influence sperm motility and conception rates of dairy cows. Journal of Dairy Science. 88(11): 3868-3875.

Funk, D.A. (2006). Major advances in globalization and consolidation of the artificial insemination industry. Journal of Dairy Science. 89: 1362-1368.

Hammonds, T. (2016). A study of the integration of artificial insemination into the dairy sector of the Alotra Mangro Region of Madagascar. Retrieved from https://digitalcollections.sit.edu/isp_coll ection $/ 2420$

Kaproth, M.T., Rycroft, H.E., Gilbert, G.R., Abdel-Azim, G., Putnam, B.F and Schnell, S.A., (2005) Theriogenology. 63:2535-49.

Patel, G.K., Haque, N., Madhavatar, M., Chaudhari, A.K., Patel.D.K., Bhalakiya, N., Jamnesha, N., Patel, P and Kumar, $R$ (2017). Journal of Pharmacognosy and phytochemistry. E-ISSN: 22784136 P-ISSN: 2349-8234; SP1: $307-$ 313.

Pundir, R and Dangi, P.S. (2015). Indigenous cattle of Manipur - Characterization and performance evaluation. Indian Journal 
of Animal Sciences. 85(4): 382-385.

Qureshi, A. M., Kahlid, J., Jarral, Z.A and Khan, S. A (2008). Environmental factors affecting performance traits of crossbred and local dairy cows at Mirpur Azad Jammu and Kashmir. Pakistan Journal of Agricultural Sciences. 45(2):362-71.

Razi, K. M. A., Asgar, M. A., Kabir, M. H., Bag, M. A.S and Parvez, M. M. (2010). A study on estimation of conception rate and services per conception in cattle after artificial insemination. International Journal of Biology
Research. 2(7): 25-29.

Shehu, B.M., Rekwot, P.I., Kezi, D.M., Bidoli, T.D., and Oyedokun, A.O. (2010). Challenges to Farmers' Participation In Artificial Insemination (AI) Biotechnology In Nigeria: An overview. Journal of Agricultural Extension. 14(2): 123-129.

Shindey, D. N., Dhanvijay, R.W., Bhagat, R. L and Gokhale, S.B. (2014). A note on Maharashtra State. International Journal of Tropical Agriculture. 32(3-4): 59599.

\section{How to cite this article:}

Ningthoukhongjam Linda, Fazal Ali Ahmed, K. Lalrintluanga, Dibyajyoti Talukdar and Jyoti Pawan Chutia. 2020. Studies on Practices of Artificial Insemination in Manipur. Int.J.Curr.Microbiol.App.Sci. 9(11): 3611-3617. doi: https://doi.org/10.20546/ijcmas.2020.911.432 